\title{
Creatures of habit: foraging habitat fidelity of adult female Australian sea lions
}

\author{
A. D. Lowther ${ }^{1,2, *}$, R. G. Harcourt ${ }^{3}$, D. J. Hamer ${ }^{4}$, S. D. Goldsworthy ${ }^{2}$ \\ ${ }^{1}$ University of Adelaide, North Terrace, Adelaide, South Australia, Australia \\ ${ }^{2}$ South Australian Research and Development Institute-Aquatic Sciences, Hamra Avenue, West Beach, South Australia, \\ Australia \\ ${ }^{3}$ Marine Mammal Research Group, Graduate School of the Environment, Macquarie University, North Ryde, \\ New South Wales, Australia \\ ${ }^{4}$ Australian Antarctic Division, Channel Highway, Kingston, Tasmania, Australia
}

\begin{abstract}
We examined the movement characteristics and seasonality of feeding behaviour for an endemic Australian otariid, the Australian sea lion Neophoca cinerea. By combining tracking data and stable isotope analysis of serially subsampled vibrissae from 20 adult females at 7 colonies, we were able to characterise individual foraging specialisation across $80 \%$ of the species range. Adult females expressed long-term temporal consistency in both foraging site (offshore vs. inshore) and prey selection. When seasonality in foraging behaviour was detected $(n=7)$, there was no consistency in variation of isotope ratios between individuals or colonies. Offshore-foraging sea lions fed at higher trophic levels than inshore foragers. Potentially, inshore foragers could be subdivided into those which targeted heterogeneously distributed seagrass meadows or calcarenite reef systems for different payoffs. This data highlights the importance of understanding individual specialisation and the dangers of generalising behaviour at the colony level. Individual specialisation in foraging behaviour may be a mechanism that reduces intra-specific competition, but its effectiveness will be a function of the temporal stability of individual differences. The present study is the first to identify multi-season consistency of individual foraging behaviour for any otariid. Given the long-term stability of adult female foraging behaviour, categorising individuals using a proxy measure such as whisker isotopic signature appears robust, economical, and appropriate. Such data is critical to modelling population response to anthropogenically driven fine-scale habitat modification.
\end{abstract}

KEY WORDS: Stable isotopes · Otariid · Niche specialisation · Sea lion · Whiskers · Tracking • Individual variation · Australian sea lion

Resale or republication not permitted without written consent of the publisher

\section{INTRODUCTION}

Acquisition of food is a major problem faced by marine mammal apex predators such as seals, which must constantly address the challenges presented by geographic decoupling of breeding (terrestrial) and foraging (aquatic) areas. In dynamic, heterogenous environments such as ocean ecosystems, predators that are constrained by the amount of time they can spend away from dependent offspring must rely on some form of predictable prey distribution (Gende \&
Sigler 2006, Willson \& Womble 2006, Thayer \& Sydeman 2007, Bost et al. 2008). Seals use 3 broad foraging strategies in response to the challenges of locating sufficient food to survive and reproduce: epipelagic foragers such as California sea lions Zalophus californianus (Feldkamp et al. 1989) and subAntarctic fur seals Arctocephalus tropicalis (Georges et al. 2000) focus their foraging effort in the upper water column to depths of $200 \mathrm{~m}$; mesopelagic depths $(200$ to $2000 \mathrm{~m}$ ) are the realm of predators such as the northern and southern elephant seals 
Miroungia angustirostris and M. leonina (LeBoeuf 1994, Campagna et al. 1995); while benthic foragers such as Weddell seals (Hindell et al. 2002), southern sea lions Otaria flavescens (Werner \& Campagna 1995, Thompson et al. 1998, Campagna et al. 2001), and New Zealand sea lions Phocarctos hookeri feed on the sea floor (Crocker et al. 2001).

Typically, epipelagic and mesopelagic foragers rely on predictable dynamic oceanographic features such as frontal zones and upwellings, where enhanced productivity supports higher densities of prey species (Olson \& Backus 1985, Schneider 1990). This imparts a degree of seasonality to foraging behaviour, and this has been observed in a wide variety of predators including king penguins Aptenodytes patagonicus (Guinet et al. 1997), southern elephant seals (Field et al. 2002), New Zealand fur seals (Harcourt et al. 2002), and sub-Antarctic fur seals (De Bruyn et al. 2009). As postulated by the 'meeting point' hypothesis, benthic or epibenthic prey tend to congregate around permanent topographical features such as shelf-breaks and reef systems (Langton et al. 1995, Klimley \& Holloway 1999, Fréon \& Dagorn 2000), making such features important to benthic predators such as yellow-eyed penguins Megadyptes antipodes (Mattern et al. 2007) and the Australian fur seal A. pusillus doriferus (Arnould \& Kirkwood 2007).

Investigating the foraging behaviour of air-breathing marine predators typically involves the use of expensive geospatial tracking devices and timedepth recorders to describe 3-dimensional movements of these large, wild, elusive predators during foraging trips to sea. Researchers face a further challenge when working with otariid seals that undergo seasonal molts, as this restricts when tracking devices can be attached, thereby defining the onset and duration of the temporal window over which tracking can occur. Thus, prohibitive costs, logistical difficulties, and the biology of animals often limits answering questions of seasonal, intersexual, and ontogenetic differences in foraging to those that may be answered using data from a small subsample of animals (Hays et al. 2003, Cronin \& McConnell 2008).

Once a population or species niche range has been defined, conspecifics tend to be treated as equals (Bolnick et al. 2003), which, from both evolutionary and conservation perspectives, has important ramifications. Yet there is a growing body of literature that suggests individual niche-width specialisation is of great importance in fur seals and sea lions (Otariidae) (Thompson et al. 1998, Staniland et al. 2004, Chilvers et al. 2005). However, the temporal window afforded by tracking is frequently relatively narrow, and so long-term temporal consistence of individual specialisation remains poorly documented. Variation in behaviours under selective pressure may provide a metric of ecological diversity and subsequent evolutionary potential. However, selective and competitive pressures will operate in markedly different ways on populations, depending upon whether individual specialisation is ephemeral, stochastic, or temporally fixed (Bolnick et al. 2003).

Individuals which are long-term foraging specialists may be able to exploit their niche more efficiently but are vulnerable to change, as they are less able to adapt to new resources when their preferred habitat becomes rare or is no longer able to sustain them. Conversely, individuals which are generalists or seasonal specialists are used to altering search images and prey-capture techniques, and are unlikely to be exposed to selection in the same way. Therefore to effectively model population responses to changes in habitat it is crucial to determine what habitat types animals use and for how long they are used (Ryall \& Fahrig 2006). When a large portion of an individual's foraging behaviour remains cryptic, as is the case with fur seals and sea lions, modelling potential changes in species distribution under climate change-driven habitat alteration becomes problematic at best (Kaschner et al. 2006).

Attempts to characterise the individual specialisation in foraging behaviour must overcome temporal constraints yet remain financially and logistically plausible. Recently, the use of cost-effective stable isotope biogeochemistry has provided great insights into foraging ecology across a range of marine mammals (see Crawford et al. 2008 for review). There is strong support for the upward cascade of stable nitrogen isotopes $\left(\delta^{15} \mathrm{~N}\right)$ from primary producers to the top of the food web. In marine ecosystems a decreasing stable carbon ratio $\left(\delta^{13} \mathrm{C}\right)$ gradient has been identified with distance from shore (Hobson et al. 1996, Post 2002). Isotope ratios provide ecological geotrophic data that has been used to describe temporal and individual variation in foraging location and diet outside the scope of traditional tracking methods using $\delta^{13} \mathrm{C}$ and $\delta^{15} \mathrm{~N}$ from metabolically active (blood) and inert (vibrissae, feathers) tissues for several seal and marine bird species (Forero \& Hobson 2003, Aurioles et al. 2006, Bearhop et al. 2006, Awkerman et al. 2007, Lowther \& Goldsworthy 2010). Recently multi-year, individual variation in foraging behaviour has been described using isotope values from serially subsampled adult male Antarctic fur seal vibrissae (Cherel et al. 2009). 
The biogeography and unique reproductive ecology of the Australian sea lion Neophoca cinerea make characterising its foraging ecology challenging. Distributed from the Pages Islands in South Australia to the Houtman Abrolhos Islands in Western Australia, a species census estimate of 13000 individuals makes the species one of the rarest otariids in the world and listed as endangered on the International Union for Conservation of Nature (IUCN) 'Red List'. Adult female Australian sea lion natal site philopatry is among the strongest observed in mammals, with temporally asynchronous breeding episodes occurring between colonies separated by as little as $30 \mathrm{~km}$ of water (Campbell et al. 2008), which may suggest that adult female Australian sea lions are not dependent on seasonality of prey resource.

Two recent studies have identified inter-individual variation in foraging behaviours of adult female Australian sea lions, which are characterised as benthic predators (Costa \& Gales 2003); individuals which forage in shallow, coastal waters $(<10 \mathrm{~m})$ and those which forage offshore in waters up to $120 \mathrm{~m}$ (Baylis et al. 2009, Lowther \& Goldsworthy 2010). However, neither study was able to characterise the temporal stability of these 2 behaviour types, though previous short-term deployments (>30 d) of telemetry devices on adult females suggested foraging site fidelity over the duration of tracking events (S. D. Goldsworthy unpubl. data). With this in mind, the present study had 2 interdependent aims: (1) to establish the temporal fidelity to previously detected alternate foraging behaviours of adult female Australian sea lions across a large portion of their range using a synergistic combination of tracking and stable isotope analysis of serially-subsampled vibrissae, and (2) to determine whether individual foraging specialisation resulted in significantly different phenotypes using proximal metrics of movement, diving, and morphology.

\section{MATERIALS AND METHODS}

\section{Study sites and sampling}

Whisker samples, depths, and location data were collected from 20 adult female Australian sea lions at 7 breeding colonies spanning the South Australian range of the species between October 2006 and June 2009 (Fig. 1). Females were captured, restrained, and anaesthetised using isofluorane delivered through a portable gas anaesthesia machine (5\% induction, 0.5

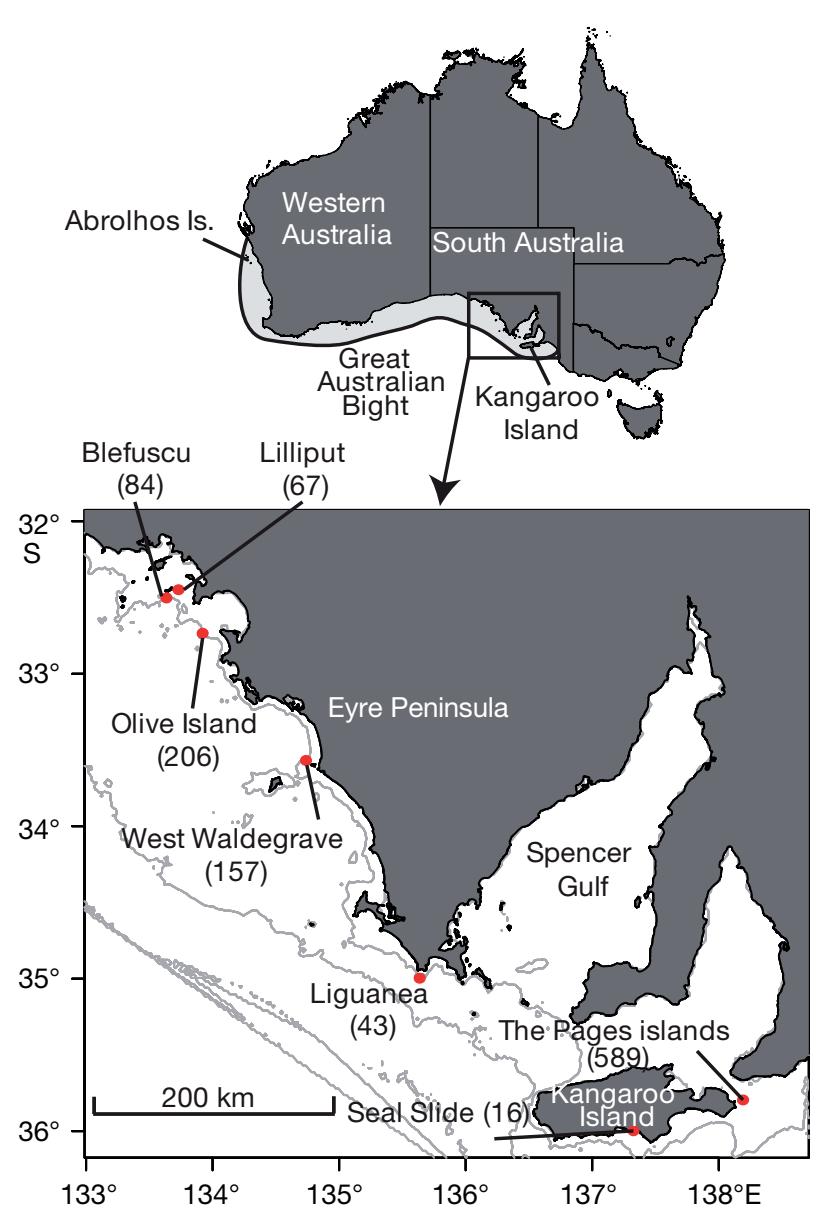

Fig. 1. Neophoca cinerea. The endemic Australian sea lion is distributed from Kangaroo Island in South Australian through to The Abrolhos Islands in Western Australia (light relief). Inset: our 7 study sites (breeding colonies; red dots) along the South Australian range of Australian sea lions, encompassing $80 \%$ of the entire species. Numbers in parentheses represent approximate pup production (Goldsworthy et al. 2009). Bathymetry lines are at $50 \mathrm{~m}$ increments to $200 \mathrm{~m}$. Geospatial and isotopic data were collected from 20 adult females across 7 breeding colonies between 2006 and 2009

to $3 \%$ maintenance; Veterinary Companies of Australia). After anaesthetic induction, the sea lion was secured on a stretcher and suspended from a spring balance (Salter Weigh-Tronix; $100 \mathrm{~kg}, 0.5 \mathrm{~kg}$ increments). Standard length and axillary girth measurements were recorded, and a whisker was sampled by clipping at its base. Kiwisat ARGOS satellite-linked transmitters (pre 2008) or archival fastloc GPS logging devices (Sirtrack), sampling at 15 min intervals in conjunction with time-depth recorders (mk9 TDR, Wildlife Computers) sampling at depth increments of $2 \mathrm{~m}$ and $1 \mathrm{~s}$ intervals, were attached to the pelage 1 hand span distal to the midpoint on the back of each adult female using 2-part epoxy glue (Araldite 
2017, Vantico, or RS Components). Devices were left attached for at least 1 foraging trip (determined either by observed departure and arrival or attendance with and subsequent absence from their pup), whereupon adult females were recaptured and the devices removed.

All vibrissae were cleaned in a method similar to that used for human hair (O'Connell \& Hedges 1999) and southern elephant seal Mirounga leonina vibrissae (Lewis et al. 2006). Briefly, vibrissae were cleaned individually for $20 \mathrm{~min}$ with de-ionised water, then with a solution of 2:1 methanol:chloroform for a further $20 \mathrm{~min}$ to remove lipids, followed by a final clean with de-ionised water for an additional 20 min. Each whisker was checked under a stereomicroscope for any remaining tissue or dirt; contaminants were removed using a scalpel blade. All samples were then rinsed with distilled water and left to air-dry overnight in a fume cupboard.

Available data on otariid whisker growth rates suggest linear growth at a rate of $\sim 3 \mathrm{~mm} \mathrm{mo}^{-1}$ (Hirons et al. 2001, Cherel et al. 2009). This may apply to Australian sea lions, but in the absence of species specific data, we refer to each $3 \mathrm{~mm}$ segment as a time-step. Vibrissae were cut into $3 \mathrm{~mm}$ segments starting at the base and the middle $1 \mathrm{~mm}$ of each segment was placed in labelled $7 \mathrm{ml}$ glass scintillation vials. All samples for isotope analysis were analysed at the Australian National University Environmental Biology Stable Isotope Facility. Analysis was performed using a Microass isoChrom CFIR mass spectrometer coupled to a Carlo Erba EA-1100 CHN-O analyser. The standard control ratio for ${ }^{13} \mathrm{C}$ and ${ }^{15} \mathrm{~N}$ were Pee Dee Belemnite and atmospheric nitrogen, respectively. Observed error rates were recorded as $< \pm 0.1 \%$ o $\left(\delta^{13} \mathrm{C}\right)$ and $< \pm 0.3 \%$ o $\left(\delta^{15} \mathrm{~N}\right)$.

\section{DATA ANALYSIS}

\section{Geospatial data processing}

Raw GPS, platform terminal transponder (PTT), and time depth recorder (TDR) data were downloaded and processed using proprietary software (Sirtrack Fastloc Admin Tool ver. 1.1.5.8 and Wildlife Computers Mk9 Host ver. 1.09.1028). We divided geospatial data into 2 groups based on spatial resolution of the telemetry data: (1) high-quality data comprising both GPS and TDR data $(\mathrm{n}=12)$ or just GPS data $(n=4)$ were filtered by excluding locations fixed by 4 or less satellites (Bradshaw et al. 2007), and dive data extracted at $1 \mathrm{~s}$ intervals; (2) lower-quality PTT datasets $(\mathrm{n}=4)$ were filtered using an iterative backwards-forwards filter that excludes locations associated with implausible swim speeds (McConnell et al. 1992). For the 16 GPS datasets, foraging trip start and end times were identified by the first and last inwater GPS locations. The mean swim speed between the first and last 2 filtered in-water PTT positions of a trip were used to estimate departure and arrival times of the remaining 4 sea lions. For each trip of each sea lion, new positions were interpolated at 10 min intervals assuming straight-line travel and constant speed between GPS or Argos fixes using the 'trip' package in R (R Development Core Team 2010).

\section{Segregation of adult female Australian sea lions into alternate foraging ecotypes}

We employed the methods in Lowther \& Goldsworthy (2010) to classify individual sea lions into significantly different foraging behaviours (ecotypes). To determine the broad-scale distribution of foraging effort, a fixed-kernel core range at the $50 \%$ utilisation distribution (UD-50) using least squares cross validation (LSCV) (Worton 1989, Börger et al. 2008) was calculated for each sea lion over all trips using the R package 'adehabitat'.

A foraging trip representative of the calculated $50 \%$ UD was selected at random for each sea lion and used for all subsequent analyses. Zero offset correction and behavioural analysis of dive data was conducted using the $\mathrm{R}$ package diveMove. Data exploration suggested that the definition of diving (submergence event $>6 \mathrm{~m}$ ) used in other studies of Australian sea lions (Costa \& Gales 2003) may exclude large portions of dive data for some sea lions foraging close to shore. We therefore define a dive as submergence below $4 \mathrm{~m}$ depth as a compromise between capturing the foraging behaviour of all sea lions and avoiding misidentification of dives (Waluda et al. 2010). Distance from mainland coast at the foraging-trip inflection point and mean dive depth were used to group individuals using a model-based agglomerative hierarchical clustering approach (Lowther \& Goldsworthy 2010).

Bayesian information criteria (BIC) was used to select the optimal number of clusters, and a posteriori classification success was assessed using leave-oneout cross-validated quadratic discriminant analysis (LOOCV-QDA). Clusters were defined as representing inshore and offshore foraging ecotypes based on significant differences in mean behavioural parameters of individuals. 


\section{Stability of foraging behaviour over time}

As vibrissae were clipped and not plucked, we assumed the first time-step was contained in the folicle and the first segment analysed represented feeding from 2 time-steps prior to sampling. Mean values for $\delta^{13} \mathrm{C}$ and $\delta^{15} \mathrm{~N}( \pm \mathrm{SE}$ ) (across multiple time-steps, range 1 to 24 ), were calculated for each sea lion and for each ecotype. To quantify temporal variation in foraging behaviour we fitted univariate ARIMA $(p, d$, $q)$ (autoregressive integrated moving average) models to stable carbon $\left(\delta^{13} \mathrm{C}\right)$ and nitrogen $\left(\delta^{15} \mathrm{~N}\right)$ isotope values using the 3-step Box Jenkins method (Box et al. 1994) (see 'Methods' section in Supplement 2 at www.int-res.com/articles/suppl/m443p249_supp.pdf). As SARIMA modelling requires sample sizes greater than the number of parameters to be estimated (Makridakis et al. 2008), only individuals with $>18$ isotopic measurements/time-steps were considered $(\mathrm{n}=14)$.

Visual inspection of isotope plots and autocorrelograms were used to determine whether data required differencing to achieve stationarity and to identify the number of parameters to be estimated. Conditional sum of squares (to assess initial parameter values), followed by exact maximum likelihood methods, was employed to estimate each parameter (Gardner et al. 1980). Finally, models were validated by checking for autocorrelation of residuals using autocorrelograms and portmanteau tests (Ljung-Box $Q$ statistic) (Ljung \& Box 1978). Optimal SARIMA models were then selected using Bayesian information criteria (BIC), as this method penalises overfitting and is widely used in time series analyses (Hurvich \& Tsai 1989).

\section{Identification of individual foraging areas}

First passage time (FPT) was used to identify the scale at which area restricted search (ARS) was conducted (Pinaud 2008, Bailey et al. 2009). To perform FPT, each track was redescretized into $50 \mathrm{~m}$ step lengths and a new time index interpolated for each new position. The FPT of circle radii ranging from $0.05 \mathrm{~km}$ to twice the maximum daily step length (Bradshaw et al. 2007) were calculated and the radii responsible for varlog $\max _{\max }$ FPT identified for each sea lion (herein referred to as ARS patch size). FPT values for this radii were then plotted against time for each trajectory, with ARS behaviour being inferred at segments of tracks that took the longest time to traverse (i.e. expressed maximum FPT values) (Hamer et al. 2009, Bailleul et al. 2010, Votier et al. 2011).
Mean parameters of time spent, distance covered, and speed $\left(\mathrm{km} \mathrm{h}^{-1}\right)$, depth $(\mathrm{m})$, bottom time (time spent at $>80 \%$ of maximum depth [min]), dive duration (min), dive rate (number of dives:time [min]), dive efficiency (bottom time:[dive duration + postdive interval]), and proportion of dives conducted were calculated for all locations that occurred within ARS patches and during transit. To characterise whether individuals preferred foraging in areas of variable bottom topography, we used the standard error of mean dive depths during transit and within ARS patches as a metric for bathymetric gradient (Burns et al. 2008), making the assumption that Australian sea lions dive benthically throughout a foraging trip (Costa \& Gales 2003, Fowler et al. 2006). Nautical twilight times for each foraging trip were collated from Geoscience Australia and used to assess the propensity of adult female Australian sea lions to forage nocturnally by calculating the proportion of ARS dives that occurred at night.

\section{Morphometric and ecotype-specific differences in movement and diving behaviour}

As model fitting has the potential to provide a close fit to data without being biologically informative, we refrained from including every parameter into a single model and opted to separate behavioural parameters into 'movement' (speed, distance, ARS patch size, and time spent transiting and foraging) and 'diving' (rate, efficiency, depth, SE of mean depth, duration, bottom time, and number of dives) (Kimura \& Weiss 1964, Villegas-Amtmann et al. 2008). We modelled the relative importance of mean behavioural parameters in predicting ecotype membership using a series of generalised additive models (GAM) using the 'gam' package in R. Parameters that were normally distributed were modelled against foraging ecotype using generalised linear models (GLM). Residuals were checked for normality of distribution (Shapiro-Wilks test) and lack of correlation with fitted values (ANOVA). For all GAM we assumed a binomial distribution for the response variable (ecotype) and a logit function.

We were also interested to examine the interplay between foraging behaviour, body condition, and age. For the 12 adult females that were measured, we used body length (as a proxy for the age of adult females) (McKenzie et al. 2007) and the residuals from regressing mass on length (as a body condition index, BCI) (Trites 1991, McDonald et al. 2009) as predictors in 2 generalised additive mixed models 
(GAMM) using a Poisson distribution with an identity link. We included ecotype as a fixed effect and behavioural parameters as random effects. A stepwise forwards and backwards model selection process based on Akaike information criteria (AIC) was used to select the parsimonious model (Hastie \& Tibshirani 1990).

\section{Statistical analyses}

All statistical analyses were conducted within the $\mathrm{R}$ framework and OriginPro Lab ver. 8. Values are reported as mean $( \pm \mathrm{SE})$ and significant at $\mathrm{p}<0.05$ unless otherwise stated.

\section{RESULTS}

\section{Inshore and offshore foraging ecotype designation}

Between October 2006 and June 2009 GPS $(\mathrm{n}=16)$ and PTT ( $\mathrm{n}=4)$ datasets were collected from 20 adult female Australian sea lions along the South Australian range of the species (Fig. 1) recording an average of $616( \pm 139)$ GPS and $802( \pm 259)$ Argos

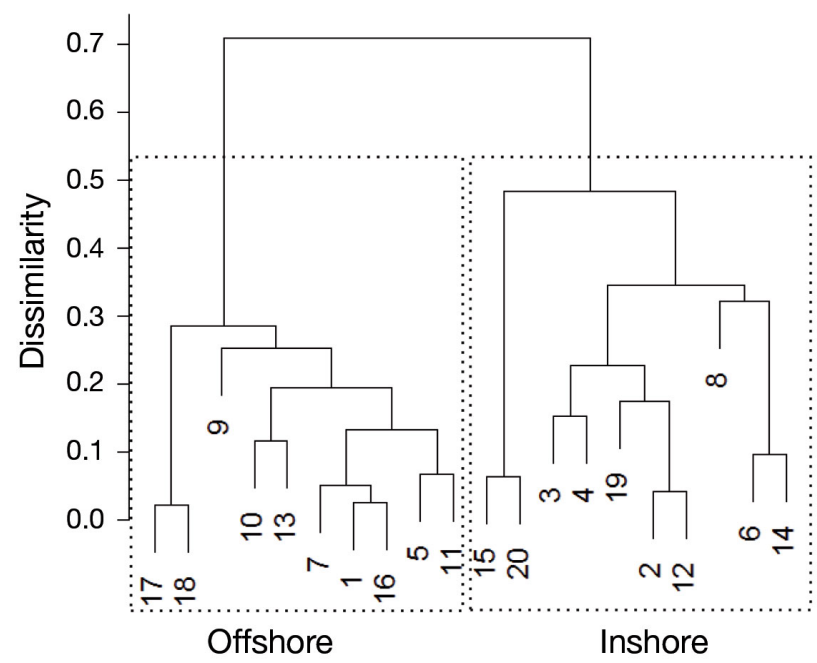

Fig. 2. Neophoca cinerea. Dendrogram displaying alternate foraging ecotypes of 20 adult female Australian sea lions sampled between June 2006 and Jun 2009 at 7 breeding colonies in South Australia. Optimal clusters were determined using maximum value Bayesian information criteria (BIC) modelling of hierarchical agglomerative clustering of mean dive depth and mean distance from the mainland coast at foraging trip inflection point for all trips of each sea lion (leave-one-out cross-validated classification success = $99 \%$ ). Numbers represent individual adult female ID number (see Table S1) locations per sea lion. Average tracking duration was $30 \mathrm{~d}( \pm 8.5)$ (range 2.7 to $113.1 \mathrm{~d})$ capturing $\sim 10( \pm 2.4)$ foraging trips per sea lion (range 1 to 45 ) (Table S1 in Supplement 1 at www.int-res.com/articles/suppl (m443p249_supp.pdf). Filtering and removal of hauled-out locations left $\sim 67( \pm 10)$ GPS and $28( \pm 9)$ Argos locations per foraging trip at an average of 1.3 $( \pm 0.19)$ and $0.25( \pm 0.05)$ GPS and Argos positions, respectively, per at-sea hour. Archival dive recorders were recovered from 14 sea lions and dive data collected at $1 \mathrm{~s}$ resolution. Throughout the tracking period, an average $1534( \pm 491)$ dives were recorded for each sea lion (range 344 to 6121) with individual mean depths ranging from $5.3( \pm 0.41)$ to $86.4 \mathrm{~m}$ $( \pm 11.4)$ (Table S1). The highest-value BIC model incorporating mean parameters of distance from shore and dive depth at the foraging trip inflection point calculated for all trips combined for each individual described 2 distinct clusters (Fig. 2). These clusters were strongly supported by LOOCV-QDA (99\% classification success), and henceforth sea lions are referred to as expressing either 'inshore' or 'offshore' foraging ecotypes. Kernel density estimates of UD-50 for individuals were invariant between ecotypes and scale-independent of the number of foraging trips recorded (Wilcoxon $\mathrm{W}=32, \mathrm{p}=0.19$ and Kruskal-Wallis $\chi^{2}=13.7, \mathrm{p}=0.24$, respectively), ranging from 5.2 to $1582.7 \mathrm{~km}^{2}$ (mean $227.7 \pm 90.2 \mathrm{~km}^{2}$ ) (Fig. 3).

\section{Stability of foraging behaviour over time}

Adult female Australian sea lion whisker lengths were normally distributed (Shapiro-Wilks W $=0.95$, $\mathrm{p}=0.36$ ), ranging from 56 to $241 \mathrm{~mm}$ (mean $125.2 \pm$ $9.35 \mathrm{~mm}$ ) with between 12 and 24 whisker segments being analysed for $\delta^{13} \mathrm{C}$ and $\delta^{15} \mathrm{~N}$ (Table S2). Individual sea lion isotope signatures varied between -11.9 to $-18.4 \%$ o $\left(\delta^{13} \mathrm{C}\right)$ and 11.6 to $16.8 \%\left(\delta^{15} \mathrm{~N}\right)$ (Fig. 4 ). Generally, significant within-colony differences in mean $\delta^{13} \mathrm{C}$ values followed expectations for characterising inshore and offshore foraging behavior, with the exception of Liguanea and The Pages Islands (Student's $t$-test $t>13.5, \mathrm{p}<0.001$ in all significant cases). Within-colony differences between alternate foraging ecotype $\delta^{15} \mathrm{~N}$ ratios were all significantly different (Student's $t$-test $t>4.9, \mathrm{p}<0.05$ in all cases); however, a priori expectations of offshore foragers expressing higher $\delta^{15} \mathrm{~N}$ ratios were reversed at Olive Island, West Waldegrave, and Seal Slide (Table 1).

Autoregressive modelling detected significant seasonal components to temporal variation in $\delta^{15} \mathrm{~N}$ or 

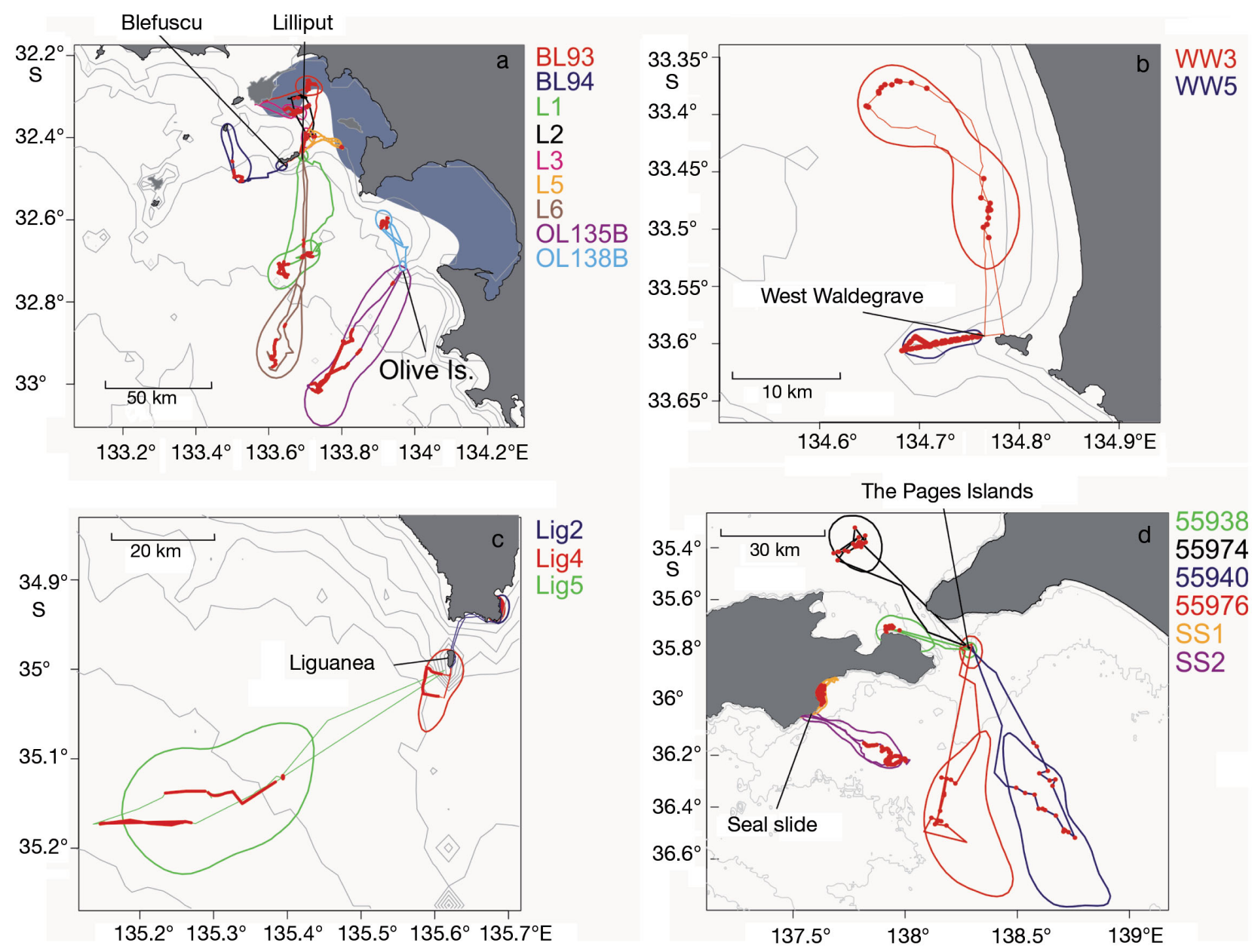

Fig. 3. Neophoca cinerea. Representative tracking data from 20 adult female Australian sea lions tracked at (a) The Nuyts Archipelago, (b) West Waldegrave, (c) Liguanea Island, and (d) The Pages Islands and Seal Slide. Red points are locations identified by first passage time (FPT) as representing area restricted searching. Areas of seagrass habitat are shown in blue (Edyvane 1999). Individuals travelled similar distances during foraging trips irrespective of foraging ecotype. Ellipses represent the $50 \%$ home range utilisation distribution of space of all trips for each individual sea lion calculated by fixed kernels and are colour-coordinated with individual tracks. Kernel home range size estimates were not affected by deployment duration and did not differ significantly between alternate foraging ecotypes. Grey lines represent changes in bathymetric slope derived from a 9 arc-second bathymetry digital elevation model. Sea lions which foraged offshore displayed a preference for more variable bottom topography characterised by greater mean foraging dive depth SE

$\delta^{13} \mathrm{C}$ ratios of 7 sea lions, with no significant autocorrelation of residual values, indicating our models were appropriate (Ljung-Box $Q<2.8, \mathrm{p}<0.1$ in all cases). Seasonality of $\delta^{13} \mathrm{C}$ and $\delta^{15} \mathrm{~N}$ SARIMA models were mainly characterised in 6- or 12-unit time-steps, with 3 individuals expressing identical time-step seasonality in both $\delta^{13} \mathrm{C}$ and $\delta^{15} \mathrm{~N}$ (Table S3 in Supplement 1 at www.int-res.com/articles/suppl/m443 p249_supp.pdf). Stable isotope data from an additional 3 sea lions required differencing in order to achieve stationarity (LIG2, OL138B, and BL94). Only 3 sea lions (L1, L6, and 55938) displayed AR(1) structured isotope measurements, whilst one (L3) was characterised by an AR(2) structure.

\section{Movement patterns of individuals}

Using data from randomly selected foraging trips representative of UD-50, instrumented sea lions undertook foraging trips between 0.4 and $3.5 \mathrm{~d}$ duration (mean $1.5 \pm 0.17 \mathrm{~d}$ ) with corresponding variation in total distance travelled (range 15.5 to $216.3 \mathrm{~km}$, mean $87.8 \pm 13.23 \mathrm{~km}$; ANOVA $F_{1,18}=36.1, \mathrm{p}<0.001$, $\mathrm{R}^{2}=67 \%$ ). Total time spent and distance travelled whilst at sea did not differ significantly between adult females from alternate foraging ecotypes (Student's $t$-test $t<0.6, \mathrm{p}>0.58$ in both cases). Optimal FPT radius identified by varlog $\max _{\max } \mathrm{FPT}$ ranged from 0.05 to $8.9 \mathrm{~km}$ (mean $2.3 \pm 0.56 \mathrm{~km}$ ) and was unre- 
a

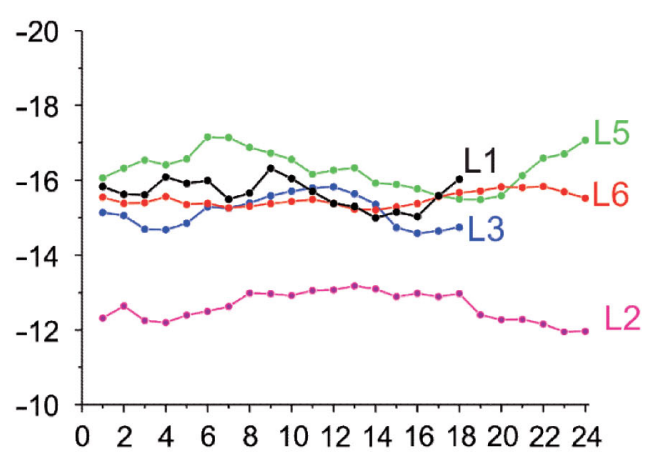

b

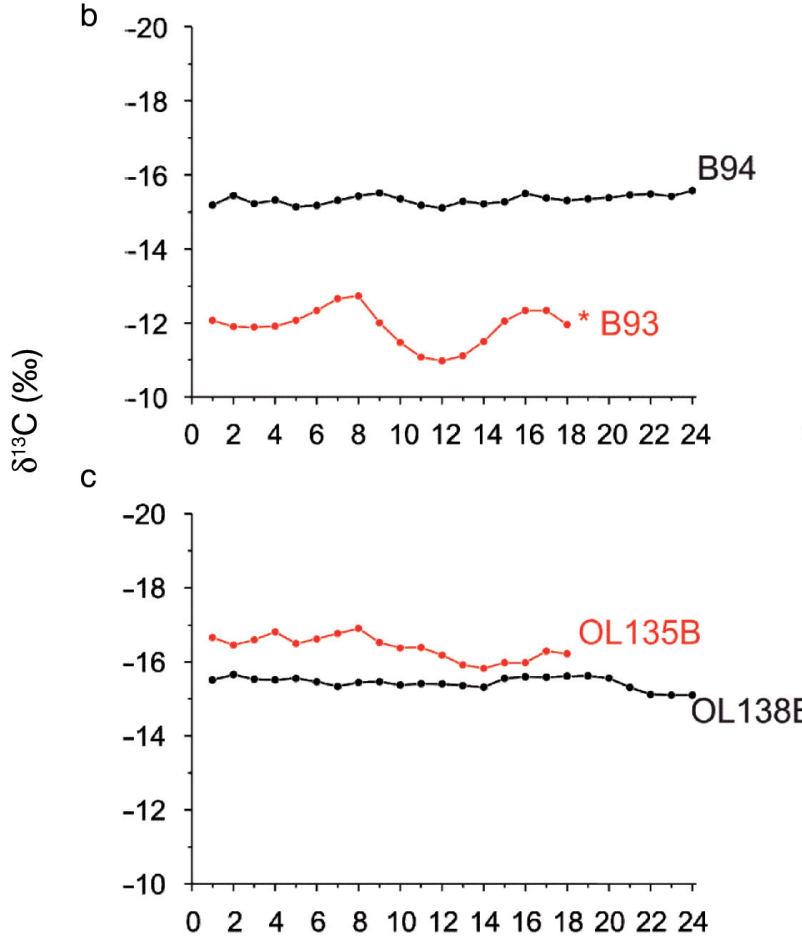

d

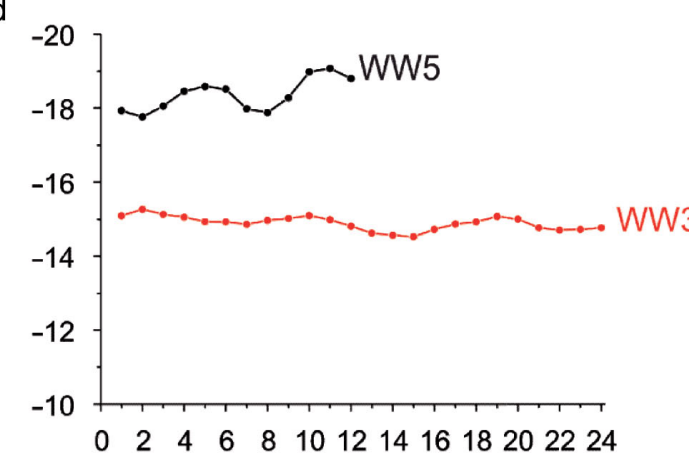

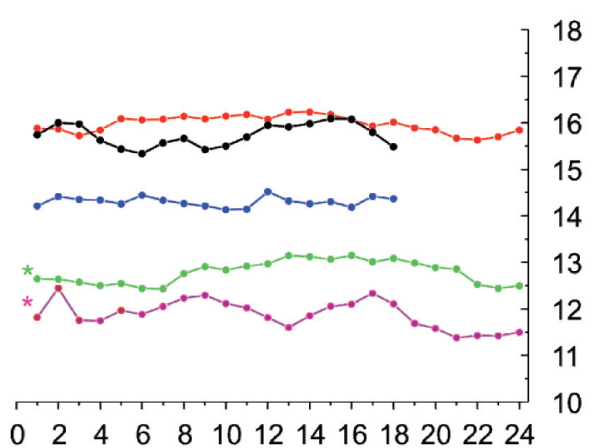
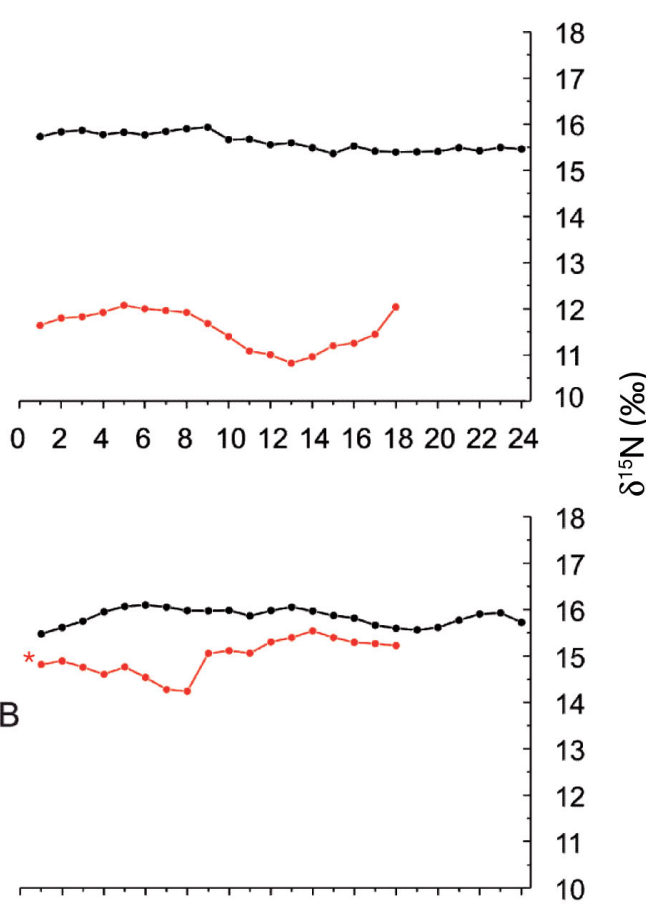

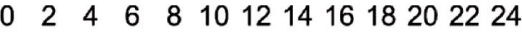

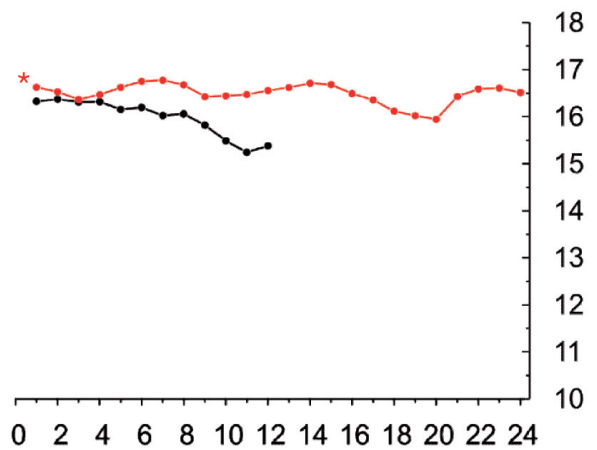

Time step

Fig. 4. Neophoca cinerea. $\delta^{13} \mathrm{C}$ and $\delta^{15} \mathrm{~N}$ isotope plots for serially subsampled adult female Australian sea lion vibrissae (3 mm segments) from (a) Lilliput Island, (b) Blefuscu Island, (c) Olive Island, (d) West Waldegrave, (e) Liguanea, (f) Seal Slide, and (g) The Pages Island. Each subsample approximates feeding behaviour incorporated into 1 time step assumed to represent 1 mo of growth. Most recent sample is at time step $1 .{ }^{*}$ adult females with 18 or more measurements $(\mathrm{n}=14)$ who expressed seasonal structure (either 6 or $12 \mathrm{mo}$ ) in one or both stable isotopes $(\mathrm{n}=7$ ). Stable isotope data from an additional 4 sea lions required differencing in order to achieve stationarity. The remaining individuals were parsimoniously characterised as corre- 
e
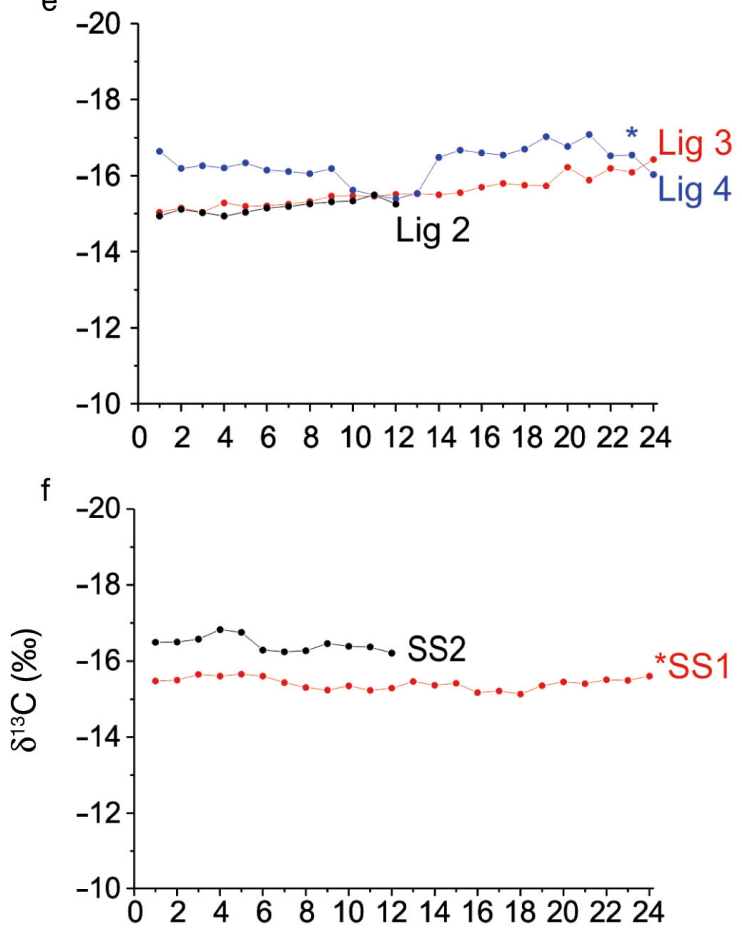

g

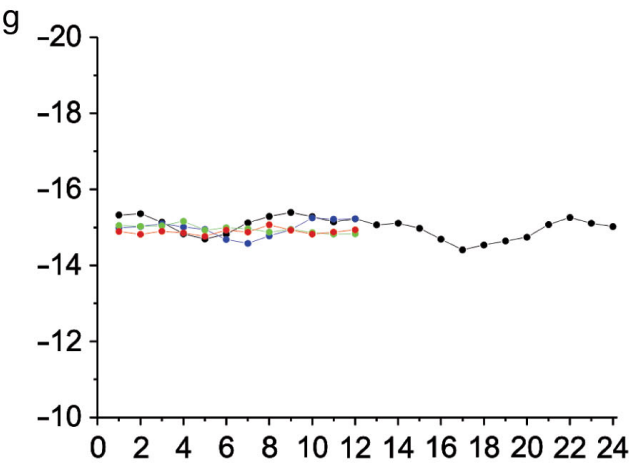

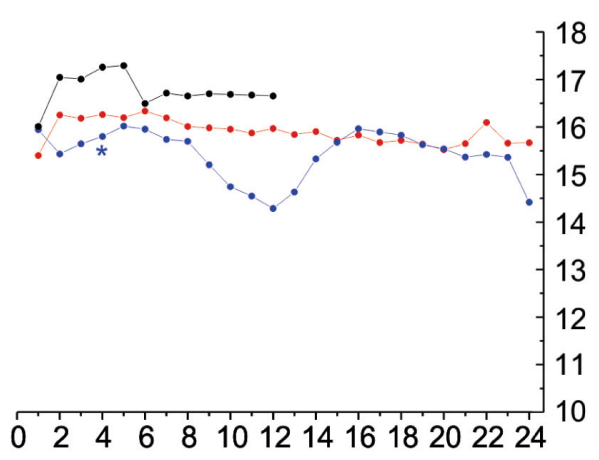
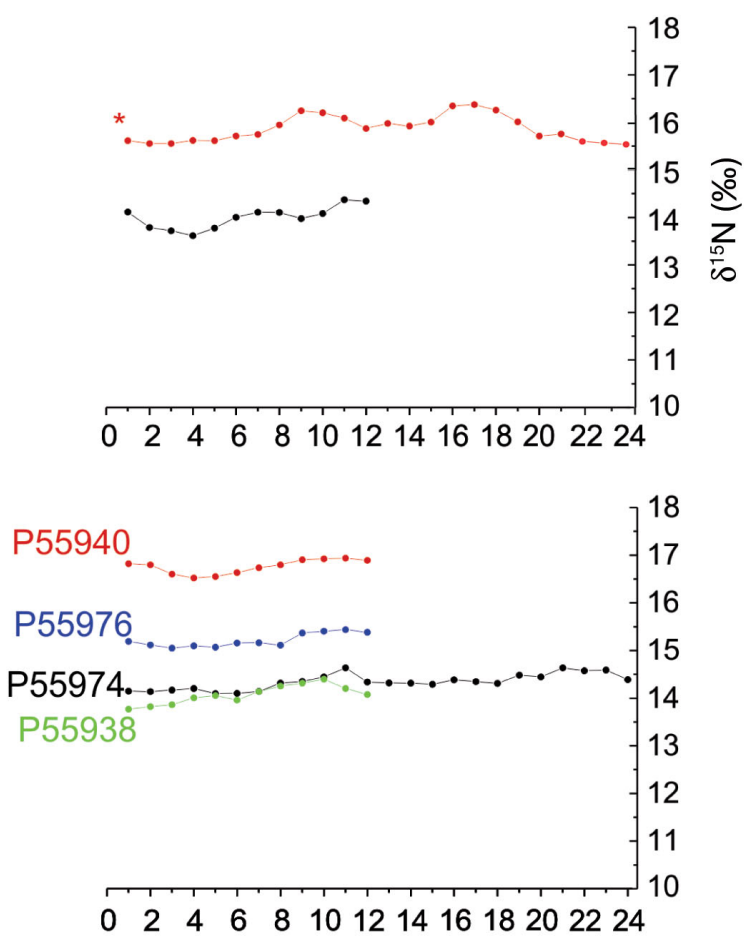

Time step

Fig. 4 (continued)

lated to foraging ecotype (ANOVA $F_{1,18}=2.6, \mathrm{p}=$ 0.13). Locations identified within ARS patches along each track are highlighted in Fig. 3. In all cases where both behavioural modes were identified, individuals swam significantly faster and travelled further during transit than when inside an ARS patch (Mann-Whitney $U=154, \mathrm{p}<0.05$ in both cases; Table $\mathrm{S} 1)$. Individual sea lions displayed no significant differences in time spent, distance covered, diving rate, and diving efficiency in each behaviour (Mann-Whitney $U=83, \mathrm{p}=0.53$ in all cases). Transit distance was the only movement parameter to successfully predict ecotype membership, with offshore-foraging sea lions travelling further than inshore-foragers (binom- inal GAM [bGAM] $\left.\chi^{2}=6.4, \mathrm{p}<0.05\right)$, although ARS patch size differences did approach significance (bGAM $\chi^{2}=7.28, p=0.06$ ). Offshore-foraging adult females also appeared to prefer foraging in regions of variable benthic topography $\left(\mathrm{bGLMz}_{\text {(mean foraging }}\right.$ depth SE) $=1.9, \mathrm{p}=0.05$ ) (Shapiro-Wilks $\mathrm{W}_{\text {(model residuals) }}$ $=0.98, \mathrm{p} \approx 1, \mathrm{ANOVA}_{\text {(fitted vs residuals) }} F_{1,12}=0, \mathrm{p} \approx 1$ ). Adult female body length and mass were unrelated to foraging ecotype; however, body condition was significantly poorer in offshore foragers and sea lions with slow transit swimming speeds (GAMM T $>6.7, \mathrm{df}=7, \mathrm{p}<0.01$ in both cases) irrespective of the trophic level of foraging (ANOVA $F_{1,10}=0.18$, $\mathrm{p}=0.68)$. 
Table 1. Neophoca cinerea. Colony-level mean $\delta^{13} \mathrm{C}$ and $\delta^{15} \mathrm{~N}$ ratios for serially subsampled vibrissae from 20 adult female Australian sea lions across the South Australian range of the species. Numbers in parentheses represent sample size. Mean inshore $\delta^{13} \mathrm{C}$ values were significantly lower than offshore values, with the exception of Liguanea and The Pages Islands (Student's $t$-test $t>13.5, \mathrm{p}<0.001$ in all significant cases). Offshore foragers also fed at a significantly higher trophic level, with the exception of individuals at Olive Island, West Waldegrave, and Seal Slide

\begin{tabular}{|c|c|c|c|c|c|c|c|c|}
\hline \multirow{2}{*}{ Colony } & \multicolumn{4}{|c|}{$\delta^{13} \mathrm{C}^{-}$} & \multicolumn{4}{|c|}{$-\delta^{15} \mathrm{~N}-$} \\
\hline & Inshore & $\pm \mathrm{SE}$ & Offshore & $\pm \mathrm{SE}$ & Inshore & $\pm \mathrm{SE}$ & Offshore & $\pm \mathrm{SE}$ \\
\hline Lilliput Island & $-14.7(3)$ & 0.21 & $-15.6(2)$ & 0.05 & 12.9 & 0.12 & 15.9 & 0.04 \\
\hline Blefuscu Island & $-11.9(1)$ & 0.12 & $-15.3(1)$ & 0.03 & 11.6 & 0.1 & 15.6 & 0.04 \\
\hline Olive Island & $-15.4(1)$ & 0.08 & $-16.4(1)$ & 0.03 & 15.8 & 0.04 & 14.9 & 0.09 \\
\hline West Waldegrave & $-14.9(1)$ & 0.04 & $-18.4(1)$ & 0.13 & 16.5 & 0.04 & 16 & 0.12 \\
\hline Liguanea & $-16.3(1)$ & 0.09 & $-15.4(2)$ & 0.06 & 15.4 & 0.11 & 16.2 & 0.08 \\
\hline Seal Slide & $-15.4(1)$ & 0.03 & $-16.4(1)$ & 0.06 & 15.9 & 0.06 & 13.9 & 0.07 \\
\hline Pages Island & $-14.9(2)$ & 0.04 & $-14.9(2)$ & 0.03 & 14.3 & 0.04 & 15.5 & 0.27 \\
\hline
\end{tabular}

\section{DISCUSSION}

The present study supports the partitioning of adult female Australian sea lion foraging behaviour into significantly different ecotypes (Lowther \& Goldsworthy 2010) and extends these findings over a large part of the species range. To our knowledge this is the first study identifying multi-season consistency in individual foraging behaviour of a temperate otariid species.

Top predators characterised as generalists tend to have diets dominated by relatively few main prey species but include a large number of less numerous secondary prey species, necessitating a diverse prey community structure. As such, they tend to be spatially or temporally associated with prey biodiversity and are commonly used to identify areas of ecological significance (Sergio et al. 2006, Baylis et al. 2008a). However, whether a predator population consists of true generalists or a collection of long-term individual specialists is likely to have profound effects on how conservation management and policy is formulated. The incorrect labelling of a predator population as generalists may result in the protection of habitat types that are inappropriate for individual specialists (Bolnick et al. 2003). Furthermore, the successful implementation of policy designed to protect species against threatening processes such as fisheries bycatch is contingent on understanding interaction rates (Goldsworthy \& Page 2007). These rates are likely dependent upon the spatial and temporal usage of habitat, which may be very different for generalist and specialist foragers. Examples of individual variation in foraging behaviour that is independent of environmental or life history effects are seldom reported though are more prevalent in systems with high levels of intraspecific competition (Hoffman et al. 2006). As such, several authors suggest a model of frequency- dependent prey choice, where density-dependent depletion of intrinsically valuable prey may make it more profitable for some individuals to specialise on less valuable but more available prey types (Beauchamp et al. 1997, Bolnick et al. 2003)

The presence of alternate, stable foraging ecotypes within Australian sea lion breeding colonies suggests that adult female foraging behaviour is not influenced by broad-scale environmental variability, as theoretically any adult female from a colony can reach the foraging habitat of any ecotype present at that colony. We identify long-term temporal stability of previously identified alternate foraging ecotypes of adult female Australian sea lions (Lowther \& Goldsworthy 2010) and extend these findings over a substantial part of the species range. Thus our data fit the criteria outlined by Estes et al. (2003), that true differences in foraging behaviour must be temporally persistent and unrelated to environmental or phenotypic variation.

\section{Individual long-term specialisation in foraging behaviour}

The present study demonstrates clear and unequivocal long-term individual specialisation in female Australian sea lions, previously characterised as generalist predators. The accessibility of multiple suitable habitats may require an sea lion to develop specialist foraging techniques to successfully exploit one, which may preclude exploitation of others (McLaughlin et al. 1999, Bolnick et al. 2003, Knudsen et al. 2011). Whilst no ecotype-specific bias to either detected seasonality existed, tracking and isotopic data from the present study suggest individual adult female Australian sea lions are repeatedly targeting the same foraging locations and similar trophic levels of prey. 
Influx of terrestrial organic material (including ${ }^{13} \mathrm{C}$-rich $\mathrm{C}_{4}$ and $\mathrm{CAM}$ plants), recycling of organic carbon (Crawford et al. 2008), and the presence of seagrasses (extremely rich in ${ }^{13} \mathrm{C}$ ) (Hemminga \& Mateo 1996) influence the $\delta^{13} \mathrm{C}$ values of inshore waters. Seagrass meadows in South Australia represent one of the largest temperate seagrass ecosystems in the world (Shepherd \& Robertson 1989) and are heterogeneously distributed in sheltered inshore waters throughout the range of this study. Stable carbon ratios were congruent with tracking data and followed a priori expectations of a latitudinal cline with 2 notable exceptions; Liguanea and The Pages Islands lie in a high-energy marine environment that promotes admixture with oceanic-depleted ${ }^{13} \mathrm{C}$ waters, possibly reducing any latitudinal cline to undetectable levels over the spatial scale of our study.

Limited dietary analysis of Australian sea lions suggests a broad range of prey from crustacean, teleost fish, elasmobranchs, and Little penguins Eudyptula minor spanning several trophic levels (Richardson \& Gales 1987, Gales \& Cheal 1992, McIntosh et al. 2006). This is consistent with our findings of $\delta^{15} \mathrm{~N}$ variation spanning almost 3 trophic levels. $\delta^{15} \mathrm{~N}$ values for piscivorous fishes that typically inhabit seagrass beds such as flathead Platycephalus speculator (11.5\%) and Australian salmon Arripis truttacea (12\%) (Jenkins \& Wheatley 1998, Hindell et al. 2000, Davenport \& Bax 2002, Hindell 2006) are approximately one trophic level (1 to $2 \%$ ) lower than adult female Australian sea lions at the inshore Lilliput, Blefuscu, and Pages Islands foraging locations where seagrass beds are most dense (Edyvane 1999).

Inshore foraging locations of sea lions from Olive Island, West Waldegrave, Liguanea, and the Seal Slide where seagrass was absent (Edyvane 1999) were characterised by $\delta^{15} \mathrm{~N}$ ratios approximately one trophic level higher than other inshore foragers (Table 1). The inshore habitat occupied by these adult females is dominated by heavy limestone or calcarenite reefs in high-energy marine environments (Edyvane 1999). Inshore-foraging adult female Australian sea lions from these colonies appear to prefer foraging around areas of variable bottom topography, supporting our assumption that they are targeting such habitats. All offshore-foraging sea lions (with the exception of no. WW5) expressed $\delta^{15} \mathrm{~N}$ values that were indistinguishable from inshore-reef foraging sea lions and shared a similar propensity for diving on high-relief bottom topography. Nitrogen isotope values from both these groups suggest feeding on a mixture of benthopelagic piscivores and secondary piscivores such as large fish, small sharks, and Little penguins. Conversely, it is possible both inshore groups forage on the same prey species, but the increased complexity of inshore reef systems may result in the same species being at a higher trophic level than in seagrass beds (Nagelkerken et al. 2002). We must caution that the absence of isotope data on local species necessitated basing our interpretation on isotope values of prey sampled in Bass Strait (Davenport \& Bax 2002). Australian sea lions dive benthically throughout a foraging trip, so it appears that offshore-foraging sea lions are targeting reefs and steep bathymetric gradients, capturing prey items that on balance are 1 trophic level higher than prey in seagrass.

\section{Ecotype-specific differences in movement behaviour and body condition}

A tenet of central place foraging theory is that animals must be suitably rewarded for undertaking longer foraging trips (Orians 1979). The foraging behaviour of several marine apex predators such as Cooks petrel Pterodroma cookie (Rayner et al. 2010), common guillemot Uria aalge (Burke \& Montevecchi 2009), Antarctic fur seal (Staniland et al. 2007), and chinstrap penguin Pygoscellis antarctica (Ichii et al. 2007) follow this prediction, targeting larger presumably more energy-dense prey items when foraging at greater distances from breeding locations. Our data appear in line with this expectation; offshore-foraging adult female Australian sea lions that travelled further to foraging grounds fed at the highest trophic levels. More interestingly, adult females that foraged inshore were in better condition than offshore foragers. Those sea lions that we assume fed on nearby inshore reef systems may have encountered the same quality prey items as offshore foragers, yet would have expended less resource accessing them. If no significant differences between ecotypes in foraging time equate to similar levels of prey-acquisition then an assumed increase in body condition is reasonable.

The question of whether fine-scale environmental heterogeneity significantly influences body condition is intriguing. Further intensive sampling of sea lions foraging in both inshore habitat types would prove informative.

\section{Seasonality of individual foraging behaviour}

Seasonal and geographical variation in foraging behaviour and diet has been inferred in several otari- 
ids by changes in dive and movement metrics (Boyd et al. 2002), hard part analysis of scats and regurgitates (Casaux et al. 2003), combinations of the above (Harcourt et al. 2002), and more recently using stable isotope analysis (Cherel et al. 2007, 2009). Two other Australian otariids notable for either breeding in geographical sympatry (New Zealand fur seals) or sharing a similar benthic foraging strategy (Australian fur seals) to Australian sea lions also appear to display seasonality in foraging behaviour. New Zealand fur seals, which are epipelagic predators, move from continental shelf foraging areas into deeper oceanic waters near the subtropical front during the winter (Page 2001, Baylis et al. 2008b). Australian fur seals appear to work hardest during winter months, undergoing significantly longer foraging trips, with a recent study identifying significant individual variation in preferred prey types (Arnould \& Hindell 2001, Arnould et al. 2011), though no data exists as to the temporal stability of these preferences.

To detect temporal or spatial variation in foraging behaviour and diet of apex predators using stable isotopes, a relatively large change in the trophic makeup of ingested prey is required (Bolnick et al. 2003, McCutchan et al. 2003). Adult female Australian sea lions do not appear to display uniform seasonality in foraging behaviour or diet. Our findings show limited congruence with the only other study examining Australian sea lion temporal variation in foraging behaviour, which reported seasonal variability in foraging energetics and dive behaviour (Costa \& Gales 2003). Unlike New Zealand and Australian fur seals, Australian sea lions breed in a mosaic-like fashion; a species-level, 17 to $18 \mathrm{mo}$ breeding cycle, and asynchronously breeding colonies means colonies are temporally decoupled with respect to the stage of lactation. If there were a lactation influence on foraging strategy then we would expect within-colony variation of foraging behaviour to be uniform between individuals but significantly different between colonies at different stages of breeding. With no such pattern observed, it appears that the foraging behaviour of adult female Australian sea lions is unaffected by lactation stage, and the presumed increase in energetic demands of nursing and gestation do not necessitate a change in foraging strategy. Weak, spatially and temporally stochastic seasonality observed in the present study may reflect opportunistic feeding on seasonal influx of prey items into a preferred foraging area and not a change in the location of foraging per se.

\section{CONCLUSIONS}

The present study clearly illustrates that long-term individual specialisation may confound population level generalisations. We demonstrate that the synergistic use of biogeochemical markers and tracking data is a powerful, cost-effective tool that can be used to determine the spatial and temporal utilisation of foraging habitat. In the case of central-place foragers, this technique could prove informative across a wide range of marine and terrestrial predators. Characterisation of Australian sea lions as generalist predators appears to be an oversimplification and may be misleading. Adult female Australian sea lions express foraging behaviour that appears to be geographically fixed, temporally stable, invariant to lactation stage, and probably influenced by the presence of fine-scale heterogeneity in habitat structure. The large degree of inter-individual variation in movement and dive parameters we observed suggests that extrapolating colony or population-level processes from a small subset of sea lions is inappropriate in this species. The specialisation-disturbance hypothesis predicts populations made up of individual specialists are more sensitive to habitat loss than generalists (Vázquez \& Simberloff 2002). If, as our data suggests, adult female Australian sea lions are long-term individual specialists, then the characteristic low-density of breeding colonies and the vulnerability of seagrass meadows to the potential effects of climate change means the loss of even a small proportion of adult females may result in localised extirpation. Given that adult female foraging behaviour is stable, the inferences made by employing proxies of maternal foraging behaviour can now be extended to characterise the degree and significance of individual specialisation within and between colonies across seasons and years (Lowther \& Goldsworthy 2010). Collection of fine-scale habitat data using techniques such as benthic swath mapping and baited underwater remote video will enable us to test the relationship between individual foraging behaviour and habitat type. Such data can then be used to underpin modelling colony-level reactions to alteration of critical habitats such as seagrass meadows and reef-fish assemblages.

Acknowledgements. All sea lion handling and experimentation was performed under Department of Environment and Heritage scientific permit no. A24684-7 and University of Adelaide animal ethics permit no. S-010-2008. Research was funded through the Department of Environment, Water, Heritage and the Arts' Australian Marine Mammal Centre, Australian Antarctic Division Commonwealth Environment 
Research Facilities (CERF) program; Sea World Research and Rescue Foundation and the Holsworth Wildlife Research Endowment. We acknowledge the logistical assistance of the South Australian Department of Environment and Heritage rangers and the South Australian State Emergency Services. We also thank the 3 anonymous reviewers for feedback that improved the manuscript.

\section{LITERATURE CITED}

Arnould JPY, Hindell MA (2001) Dive behaviour, foraging locations, and maternal-attendance patterns of Australian fur seals (Arctocephalus pusillus doriferus). Can J Zool 79:35-48

> Arnould JPY, Kirkwood R (2007) Habitat selection by female Australian fur seals (Arctocephalus pusillus doriferus). Aquat Cons Mar Freshw Ecosys 17:S53-S67

Arnould J, Cherel Y, Gibbens J, White J, Littnan C (2011) Stable isotopes reveal inter-annual and inter-individual variation in the diet of female Australian fur seals. Mar Ecol Prog Ser 422:291-302

> Aurioles D, Koch PL, Le Boeuf BJ (2006) Differences in foraging location of Mexican and California elephant seals: Evidence from stable isotopes in pups. Mar Mamm Sci 22:326-338

> Awkerman JA, Hobson KA, Anderson DJ (2007) Isotopic (delta N-15 and delta C-13) evidence for intersexual foraging differences and temporal variation in habitat use in waved albatrosses. Can J Zool Rev Canadien Zool 85: 273-279

> Bailey H, Mate BR, Palacios DM, Irvine L, Bograd SJ, Costa DP (2009) Behavioural estimation of blue whale movements in the northeast Pacific from state-space model analysis of satellite tracks. Endang Species Res 10: 93-106

Bailleul F, Lesage V, Hammill MO (2010) Spherical first passage time: a tool to investigate area-restricted search in three-dimensional movements. Ecol Model 221: 1665-1673

> Baylis AMM, Page B, Goldsworthy SD (2008a) Colonyspecific foraging areas of lactating New Zealand fur seals. Mar Ecol Prog Ser 361:279-290

- Baylis AMM, Page B, Goldsworthy SD (2008b) Effect of seasonal changes in upwelling activity on the foraging locations of a wide-ranging central-place forager, the New Zealand fur seal. Can J Zool Rev Canadien Zool 86: 774-789

Baylis AMM, Hamer DJ, Nichols PD (2009) Assessing the use of milk fatty acids to infer the diet of the Australian sea lion (Neophoca cinerea). Wildl Res 36:169-176

> Bearhop S, Phillips RA, McGill R, Cherel Y, Dawson DA, Croxall JP (2006) Stable isotopes indicate sex-specific and long-term individual foraging specialisation in diving seabirds. Mar Ecol Prog Ser 311:157-164

Beauchamp G, Giraldeau LA, Ennis N (1997) Experimental evidence for the maintenance of foraging specializations by frequency-dependent choice in flocks of spice finches. Ethol Ecol Evol 9:105-117

Bolnick DI, Svanback R, Fordyce JA, Yang LH, Davis JM, Hulsey CD, Forister ML (2003) The ecology of individuals: incidence and implications of individual specialization. Am Nat 161:1-28

Börger L, Dalziel BD, Fryxell JM (2008) Are there general mechanisms of animal home range behaviour? A review and prospects for future research. Ecol Lett 11:637-650

Bost C, Jaeger A, Huin W, Koubbi P, Halsey L, Hanuise H,
Handrich Y (2008) Monitoring prey availability via data loggers deployed on seabirds: advances and present limitations. In: Tsukamoto K, Kawamura T, Takeuchi T, Beard TD, Kaiser MJ (eds) Fisheries for global welfare and environment. Terrapub, Tokyo, p 121-137

Box G, Jenkins G, Reinsel G (1994) Time series analysis, forecasting and control. Prentice Hall, Eaglewood Cliffs, NJ

> Boyd IL, Staniland IJ, Martin AR (2002) Distribution of foraging by female Antarctic fur seals. Mar Ecol Prog Ser 242: 285-294

Bradshaw CJA, Sims DW, Hays GC (2007) Measurement error causes scale-dependent threshold erosion of biological signals in animal movement data. Ecol Appl 17: 628-638

> Burke C, Montevecchi W (2009) The foraging decisions of a central place foraging seabird in response to fluctuations in local prey conditions. J Zool 278:354-361

Burns J, Hindell MA, Bradshaw CJA, Costa DP (2008) Finescale habitat selection of crabeater seals as determined by diving behavior. Deep-Sea Res II 55:500-514

> Campagna C, Le Boeuf BJ, Blackwell SB, Crocker DE, Quintana F (1995) Diving behaviour and foraging location of female southern elephant seals from Patagonia. J Zool 236:55-71

Campagna C, Werner R, Karesh W, Marin MR, Koontz F, Cook R, Koontz C (2001) Movements and location at sea of South American sea lions (Otaria flavescens). J Zool 255:205-220

Campbell RA, Gales NJ, Lento GM, Baker CS (2008) Islands in the sea: extreme female natal site fidelity in the Australian sea lion, Neophoca cinerea. Biol Lett 4:139-142

Casaux R, Baroni A, Arrighetti F, Ramon A, Carlini A (2003) Geographical variation in the diet of the Antarctic fur seal Arctocephalus gazella. Polar Biol 26:753-758

> Cherel Y, Hobson KA, Guinet C, Vanpe C (2007) Stable isotopes document seasonal changes in trophic niches and winter foraging individual specialization in diving predators from the Southern Ocean. J Anim Ecol 76: 826-836

Cherel Y, Kernaleguen L, Richard P, Guinet C (2009) Whisker isotopic signature depicts migration patterns and multi-year intra- and inter-individual foraging strategies in fur seals. Biol Lett 5:830-832

Chilvers BL, Wilkinson IS, Duignan PJ, Gemmell NJ (2005) Summer foraging areas for lactating New Zealand sea lions Phocarctos hookeri. Mar Ecol Prog Ser 304:235-247

Costa DP, Gales NJ (2003) Energetics of a benthic diver: seasonal foraging ecology of the Australian sea lion, Neophoca cinerea. Ecol Monogr 73:27-43

> Crawford K, McDonald RA, Bearhop S (2008) Applications of stable isotope techniques to the ecology of mammals. Mammal Rev 38:87-107

> Crocker DE, Gales NJ, Costa DP (2001) Swimming speed and foraging strategies of New Zealand sea lions (Phocarctos hookeri). J Zool 254:267-277

Cronin MA, McConnell BJ (2008) SMS seal: a new technique to measure haul out behaviour in marine vertebrates. J Exp Mar Biol Ecol 362:43-48

Davenport SR, Bax NJ (2002) A trophic study of a marine ecosystem off southeast Australia using stable isotopes of carbon and nitrogen. Can J Fish Aquat Sci 59:514-530

$>$ De Bruyn PJN, Tosh CA, Oosthuizen WC, Bester MN, Arnould JPY (2009) Bathymetry and frontal system interactions influence seasonal foraging movements of lactating Subantarctic fur seals from Marion Island. Mar Ecol Prog Ser 394:263-276 
Edyvane KS (1999) Conserving biodiversity in South Australia. II. Identification of areas of high conservation value in South Australia. In: SARDI (ed) Book 39. Department of Primary Industries South Australia, Adelaide.

Estes J, Riedman M, Staedler M, Tinker M, Lyon B (2003) Individual variation in prey selection by sea otters: patterns, causes and implications. J Animal Ecol 72:144-155

Fauchald P, Tveraa T (2003) Using first-passage time in the analysis of area-restricted search and habitat selection. Ecology 84:282-288

Feldkamp SD, DeLong RL, Antonelis GA (1989) Diving patterns of California sea lions, Zalophus californianus. Can J Zool 67:872-883

Field I, Hindell MA, Slip DJ, Michael KJ (2001) Foraging strategies of southern elephant seals (Mirounga leonina) in relation to frontal zones and water masses. Antarct Sci 13:371-379

Forero MG, Hobson KA (2003) Using stable isotopes of nitrogen and carbon to study seabird ecology: applications in the Mediterranean seabird community. Sci Mar 67:23-32

Fowler SL, Costa DP, Arnould JPY, Gales NJ, Kuhn CE (2006) Ontogeny of diving behaviour in the Australian sea lion: trials of adolescence in a late bloomer. J Anim Ecol 75:358-367

> Fréon P, Dagorn L (2000) Review of fish associative behaviour: toward a generalisation of the meeting point hypothesis. Rev Fish Biol Fish 10:183-207

Gales NJ, Cheal AJ (1992) Estimating diet composition of the Australian sea-lion (Neophoca- cinerea) from scat analysis - an unreliable technique. Wildl Res 19:447-456

Gardner G, Harvey A, Phillips G (1980) Algorithm AS 154: an algorithm for exact maximum likelihood estimation of autoregressive-moving average models by means of Kalman filtering. Appl Stat 29:311-322

Gende SM, Sigler MF (2006) Persistence of forage fish 'hot spots' and its association with foraging Steller sea lions (Eumetopias jubatus) in southeast Alaska. Deep-Sea Res II 53:432-441

Georges JY, Bonadonna F, Guinet C (2000) Foraging habitat and diving activity of lactating Subantarctic fur seals in relation to sea-surface temperatures at Amsterdam Island. Mar Ecol Prog Ser 196:291-304

Goldsworthy S, Page B (2007) A risk-assessment approach to evaluating the significance of seal bycatch in two Australian fisheries. Biol Conserv 139:269-285

Goldsworthy SD, McKenzie J, Shaughnessy PD, McIntosh RR, Page B, Campbell RA (2009) An update of the report: understanding the impediments to the growth of Australian sea lion populations. SARDI Res Rep No. 356 (Publication no. F2008/00847-1), Department of the Environment Water Heritage and the Arts, Adelaide

> Guinet C, Koudil M, Bost CA, Durbec JP, Georges JY, Mouchot MC, Jouventin P (1997) Foraging behaviour of satellite-tracked king penguins in relation to sea-surface temperatures obtained by satellite telemetry at Crozet Archipelago, a study during three austral summers. Mar Ecol Prog Ser 150:11-20

> Hamer K, Humphreys E, Magalhaes M, Garthe S and others (2009) Fine scale foraging behaviour of a medium ranging marine predator. J Anim Ecol 78:880-889

> Harcourt RG, Bradshaw CJA, Dickson K, Davis LS (2002) Foraging ecology of a generalist predator, the female New Zealand fur seal. Mar Ecol Prog Ser 227:11-24

Hastie T, Tibshirani R (eds) (1990) Generalized additive models. Chapman \& Hall, London

> Hays GC, Broderick AC, Godley BJ, Luschi P, Nichois WJ (2003) Satellite telemetry suggests high levels of fishing- induced mortality in marine turtles. Mar Ecol Prog Ser 262:305-309

Hemminga MA, Mateo MA (1996) Stable carbon isotopes in seagrasses: variability in ratios and use in ecological studies. Mar Ecol Prog Ser 140:285-298

Hindell JS (2006) Assessing the trophic link between seagrass habitats and piscivorous fishes. Mar Freshw Res 57: 121-131

> Hindell JS, Jenkins GP, Keough MJ (2000) Evaluating the impact of predation by fish on the assemblage structure of fishes associated with seagrass (Heterozostera tasmanica) (Martens ex Ascherson) den Hartog, and unvegetated sand habitats. J Exp Mar Biol Ecol 255:153-174

Hindell MA, Harcourt R, Waas JR, Thompson D (2002) Finescale three-dimensional spatial use by diving, lactating female Weddell seals Leptonychotes weddellii. Mar Ecol Prog Ser 242:275-284

Hirons AC, Schell DM, St. Aubin DJ (2001) Growth rates of vibrissae of harbor seals (Phoca vitulina) and Steller sea lions (Eumetopias jubatus). Can J Zool Rev Canadien Zool 79:1053-1061

> Hobson KA, Schell D, Renouf D, Noseworthy E (1996) Stable-carbon and nitrogen isotopic fractionation between diet and tissues of captive seals: implications for dietary reconstructions involving marine mammals. Can J Fish Aquat Sci 53:528-533

> Hoffman J, Matson C, Amos W, Loughlin T, Bickham J (2006) Deep genetic subdivision within a continuously distributed and highly vagile marine mammal, the Steller's sea lion (Eumetopias jubatus). Mol Ecol 15: 2821-2832

Hurvich CM, Tsai CL (1989) Regression and time series model selection in small samples. Biometrika 76:297

> Ichii T, Bengtson JL, Boveng PL, Takao Y and others (2007) Provisioning strategies of Antarctic fur seals and chinstrap penguins produce different responses to distribution of common prey and habitat. Mar Ecol Prog Ser 344: 277-297

Jenkins GP, Wheatley MJ (1998) The influence of habitat structure on nearshore fish assemblages in a southern Australian embayment: comparison of shallow seagrass, reef-algal and unvegetated sand habitats, with emphasis on their importance to recruitment. J Exp Mar Biol Ecol 221:147-172

- Kaschner K, Watson R, Trites A, Pauly D (2006) Mapping world-wide distributions of marine mammal species using a relative environmental suitability (RES) model. Mar Ecol Prog Ser 316:285-310

- Kimura M, Weiss GH (1964) The stepping stone model of population structure and the decrease of genetic correlation with distance. Genetics 49:561

Klimley AP, Holloway C (1999) School fidelity and homing synchronicity of yellowfin tuna, Thunnus albacares. Mar Biol 133:307-317

Knudsen R, Siwertsson A, Adams CE, Garduño-Paz M, Newton J, Amundsen PA (2011) Temporal stability of niche use exposes sympatric Arctic charr to alternative selection pressures. Evol Ecol 25:589-604

> Langton RW, Auster PJ, Schneider DC (1995) A spatial and temporal perspective on research and management of groundfish in the northwest Atlantic. Rev Fish Sci 3: 201-229

LeBoeuf BJ (1994) Variation in the diving pattern of northern elephant seals with age, mass sex, and reproductive condition. In: LeBoeuf BJ, Laws RM (eds) Elephant seals: population ecology, behaviour, and physiology. University of California Press, Berkeley, CA 
Lewis R, O'Connell TC, Lewis M, Campagna C, Hoelzel AR (2006) Sex-specific foraging strategies and resource partitioning in the southern elephant seal (Mirounga leonina). Proc Biol Sci 273:2901-2907

Ljung GM, Box GEP (1978) On a measure of lack of fit in time series models. Biometrika 65:297

Lowther AD, Goldsworthy SD (2010) Detecting alternate foraging ecotypes in Australian sea lion (Neophoca cinerea) breeding colonies using stable isotope analysis. Mar Mamm Sci 27:567-286

Makridakis S, Wheelwright SC, Hyndman RJ (2008) Forecasting methods and applications, 3rd edn. Wiley India, New Delhi

> Mattern T, Ellenberg U, Houston DM, Davis LS (2007) Consistent foraging routes and benthic foraging behaviour in yellow-eyed penguins. Mar Ecol Prog Ser 343:295-306

McConnell B, Chambers C, Fedak M (1992) Foraging ecology of southern elephant seals in relation to the bathymetry and productivity of the Southern Ocean. Antarct Sci 4:393-398

McCutchan JH, Lewis WM, Kendall C, McGrath CC (2003) Variation in trophic shift for stable isotope ratios of carbon, nitrogen, and sulfur. Oikos 102:378-390

McDonald BI, Goebel ME, Crocker DE, Tremblay Y, Costa DP (2009) Effects of maternal traits and individual behavior on the foraging strategies and provisioning rates of an income breeder, the Antarctic fur seal. Mar Ecol Prog Ser 394:277-288

McIntosh RR, Page B, Goldsworthy SD (2006) Dietary analysis of regurgitates and stomach samples from free-living Australian sea lions. Wildl Res 33:661-669

> McKenzie J, Page B, Shaughnessy PD, Hindell MA (2007) Age and reproductive maturity of New Zealand fur seals (Arctocephalus forsteri) in southern Australia. J Mammal 88:639-648

> McLaughlin RL, Ferguson MM, Noakes DLG (1999) Adaptive peaks and alternative foraging tactics in brook charr: evidence of short-term divergent selection for sittingand-waiting and actively searching. Behav Ecol Sociobiol 45:386-395

Nagelkerken I, Roberts C, Van Der Velde G, Dorenbosch M, Van Riel M, Cocheret de la Morinière E, Nienhuis $P$ (2002) How important are mangroves and seagrass beds for coral-reef fish? The nursery hypothesis tested on an island scale. Mar Ecol Prog Ser 244:299-305

O'Connell TC, Hedges REM (1999) Isotopic comparison of hair and bone: archaeological analyses. J Archaeol Sci 26:661-666

Olson DB, Backus RH (1985) The concentrating of organisms at fronts: a cold-water fish and a warm-core Gulf Stream ring. J Mar Res 43:113-137

Orians NE (1979) On the theory of central place foraging. In: Horn J, Stairs GR, Mitchell RD (eds) Analysis of ecological systems. Ohio State University Press, Columbus, $\mathrm{OH}$, p 153-177

Page B, McKenzie J, Morrissey A, Goldsworthy SD, Hindell MA (2001) Foraging locations of lactating New Zealand fur seals from Kangaroo Island. Proc Southern Hemisphere Marine Mammal Conference, Phillip Island, Australia

> Pinaud D (2008) Quantifying search effort of moving animals at several spatial scales using first-passage time analysis: effect of the structure of environment and tracking systems. J Appl Ecol 45:91-99

Post DM (2002) Using stable isotopes to estimate trophic position: models, methods, and assumptions. Ecology 83:
703-718

R Development Core Team (2010) R: a language and environment for statistical computing. R Foundation for Statistical Computing, Vienna

Rayner M, Hartill B, Hauber M, Phillips R (2010) Central place foraging by breeding Cook's petrel Pterodroma cookii: foraging duration reflects range, diet and chick meal mass. Mar Biol 157:2187-2194

Richardson KC, Gales NJ (1987) Functional-morphology of the alimentary-tract of the Australian sea-lion, Neophoca- Cinerea. Aust J Zool 35:219-226

Ryall KL, Fahrig L (2006) Response of predators to loss and fragmentation of prey habitat: a review of theory. Ecology 87:1086-1093

Schneider DC (1990) Seabirds and fronts: a brief overview. Polar Rec (Gr Brit) 8:17-21

Sergio F, Newton I, Marchesi L, Pedrini P (2006) Ecologically justified charisma: preservation of top predators delivers biodiversity conservation. J Appl Ecol 43:1049-1055

Shepherd SA, Robertson EL (1989) Regional studies-seagrasses of South Australia, Western Victoria and Bass Strait. In: Larkum AWD, McComb AJ, Shepherd SA (eds) Biology of seagrasses. Elsevier, Amsterdam

Staniland IJ, Reid K, Boyd IL (2004) Comparing individual and spatial influences on foraging behaviour in Antarctic fur seals Arctocephalus gazella. Mar Ecol Prog Ser 275: 263-274

Staniland I, Boyd I, Reid K (2007) An energy-distance tradeoff in a central-place forager, the Antarctic fur seal (ArCtocephalus gazella). Mar Biol 152:233-241

> Thayer J, Sydeman W (2007) Spatio-temporal variability in prey harvest and reproductive ecology of a piscivorous seabird, Cerorhinca monocerata, in an upwelling system. Mar Ecol Prog Ser 329:253-265

Thompson D, Duck CD, McConnell BJ, Garret J (1998) Foraging behaviour and diet of lactating female southern sea lions (Otaria flavescens) in the Falkland Islands. J Zool 246:135-146

Trites AW (1991) Fetal growth of northern fur seals: lifehistory strategy and sources of variation. Can J Zool 69: 2608-2617

Vázquez DP, Simberloff D (2002) Ecological specialization and susceptibility to disturbance: conjectures and refutations. Am Nat 159:606-623

> Villegas-Amtmann S, Costa DP, Tremblay Y, Salazar S, Aurioles-Gamboa D (2008) Multiple foraging strategies in a marine apex predator, the Galapagos sea lion Zalophus wollebaeki. Mar Ecol Prog Ser 363:299-309

Votier SC, Grecian WJ, Patrick S, Newton J (2011) Intercolony movements, at-sea behaviour and foraging in an immature seabird: results from GPS-PPT tracking, radiotracking and stable isotope analysis. Mar Biol 158: 355-362

> Waluda CM, Collins MA, Black AD, Staniland IJ, Trathan PN (2010) Linking predator and prey behaviour: contrasts between Antarctic fur seals and macaroni penguins at south Georgia. Mar Biol 157:99-112

> Werner R, Campagna C (1995) Diving behaviour of lactating southern sea lions (Otaria flavescens) in Patagonia. Can J Zool 73:1975-1982

Willson MF, Womble JN (2006) Vertebrate exploitation of pulsed marine prey: a review and the example of spawning herring. Rev Fish Biol Fish 16:183-200

Worton B (1989) Kernel methods for estimating the utilization distribution in home-range studies. Ecology 70 : $164-168$

Submitted: June 8, 2011; Accepted: September 12, 2011

Proofs received from author(s): December 5, 2011 